\title{
Size variability and natural mortality dynamics of anchovy Engraulis japonicus eggs under high fishing pressure
}

\author{
Ruijing Wan*, Xiaodong Bian \\ Yellow Sea Fisheries Research Institute, Chinese Academy of Fishery Sciences (CAFS), 106 Nanjing Road, Qingdao, \\ Shandong 266071, PR China
}

\begin{abstract}
Since the late 1990s, the anchovy Engraulis japonicus stock in the Yellow Sea has undergone considerable decline as a result of the enormous fishing pressure there. Reproductive characteristics have changed during the same period. Fisheries surveys were conducted in anchovy spawning grounds off south Shandong Peninsula in the Yellow Sea from 2000 to 2004, and in Laizhou Bay of the Bohai Sea, the wider Yellow Sea, and in coastal waters of the East China Sea from 2003 to 2008. Anchovy eggs from the spawning grounds south of the Shandong Peninsula (16 to 29 June 2003) had long axes ranging from 1.20 to $1.40 \mathrm{~mm}(1.28 \pm 0.04 \mathrm{~mm})$, and short axes ranging from 0.60 to $0.68 \mathrm{~mm}(0.64 \pm 0.02 \mathrm{~mm})$. In the coastal area of the East China Sea $(7$ to 14 May 2007), the eggs had long axes ranging from 1.12 to $1.40 \mathrm{~mm}(1.28 \pm 0.06 \mathrm{~mm})$ and short axes ranging from 0.55 to $0.68 \mathrm{~mm}(0.63 \pm 0.03 \mathrm{~mm})$. Compared with previous research results on anchovy egg size in Chinese waters and in other coastal regions of the North Pacific from the 1950 s to 1970 s, egg size was notably decreased both at the spawning grounds off the south Shandong Peninsula and in the coastal waters of the East China Sea. The natural mortality rate of anchovy eggs was $80.15 \%$ at the spawning grounds off south Shandong Peninsula, $77.63 \%$ in the Yellow Sea, and $82.95 \%$ in Laizhou Bay of the Bohai Sea. Based on our survey data, the natural mortality rate of anchovy eggs has been as high as $80 \%$ in the Bohai Sea, the Yellow Sea, and the East China Sea since the late 1990s. Compared with survey results for the Yellow Sea from the 1980s, the natural mortality rates of anchovy eggs have shown a significant rising trend. The decreased size and significantly increased natural mortality rate of anchovy eggs are long-term adaptive responses, via the reproductive biology of the anchovy population, to the enormous fishing pressure in the study area.
\end{abstract}

KEY WORDS: Egg size · Adaptive responses $\cdot$ Yellow Sea

Resale or republication not permitted without written consent of the publisher

\section{INTRODUCTION}

The anchovy Engraulis japonicus is one of the most important fish resources in the Yellow and East China Seas (Zhu \& Iversen 1990). The annual biomass of anchovy stocks in the Yellow Sea was $205 \times$ $10^{4}$ to $410 \times 10^{4}$ t from 1986 to 1996 , and its annual yield was almost $100 \times 10^{4}$ t from 1997 to 2000 (Fig. 1) (Zhao et al. 2003). Anchovies are an abundant small pelagic fish species in the Yellow Sea. They play an important role in food production and the sustainable use of fisheries. Anchovies mainly feed on zooplankton such as the copepod Calanus sinicus or the euphausiid Euphausia pacifica. At the same time, they are a major prey species for $>40$ higher level fishes such as Scomberomorus niphonius, Pseudosciaena polyactis, and Trichiurus lepturus (Wei \& Jiang 1992). Hence, anchovies are an important 


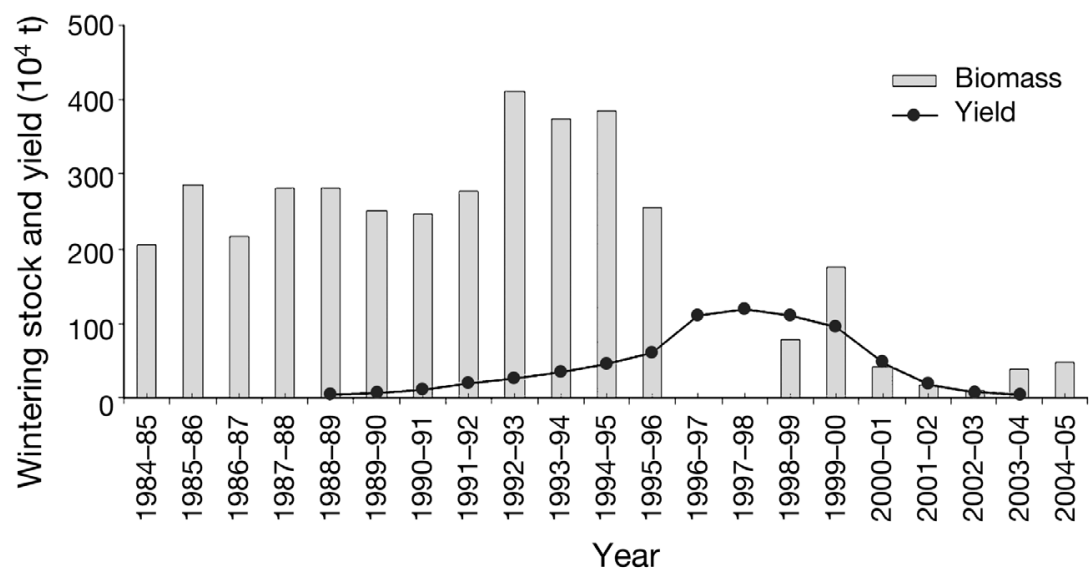

Fig. 1. Engraulis japonicus. Acoustic estimates of the wintering stock and annual yield of anchovy in the Yellow Sea, 1985-2005 (Zhao et al. 2003, Zhao 2006)

Moreover, significant changes took place in the biological characteristics of this stock. (1) A trend towards a smaller size and a lower age of the anchovy spawning stock in the Yellow Sea occured (Fig. 2) (Li et al. 2006). (2) Individual fecundity increased significantly within a certain range of fork lengths and body weights (Tables 1 \& 2) (Zeng et al. 2005). (3) The growth rates of 1 to $3 \mathrm{yr}$ old recruits increased in terms of both body length and weight (Zhu et al. 2007). These changes in biological characteristics reflect the adaptive responses of anchovy stock to maintain stock survival and sus-

intermediate link between zooplankton and higher level fish species in food webs. As such, anchovies are one of the key species in the marine ecosystem, playing an important role in energy flow and conversion (Tang et al. 2005).

Since the late 1990s, the anchovy stock in the Yellow Sea has been under enormous fishing pressure and its annual biomass dropped from $410 \times$ $10^{4} \mathrm{t}$ in 1993 to $18 \times 10^{4} \mathrm{t}$ in 2002 (Zhao et al. 2003), and to a historic low in 2003 of only $11 \times$ $10^{4} \mathrm{t}$ (Fig. 1) (Zhao 2006). The anchovy stock underwent a serious decline in just $10 \mathrm{yr}$. The annual biomass remained at a low of $25 \times 10^{4}$ to 30 $\times 10^{4}$ t during 2004 and 2005 (Fig. 1) (Zhao 2006).

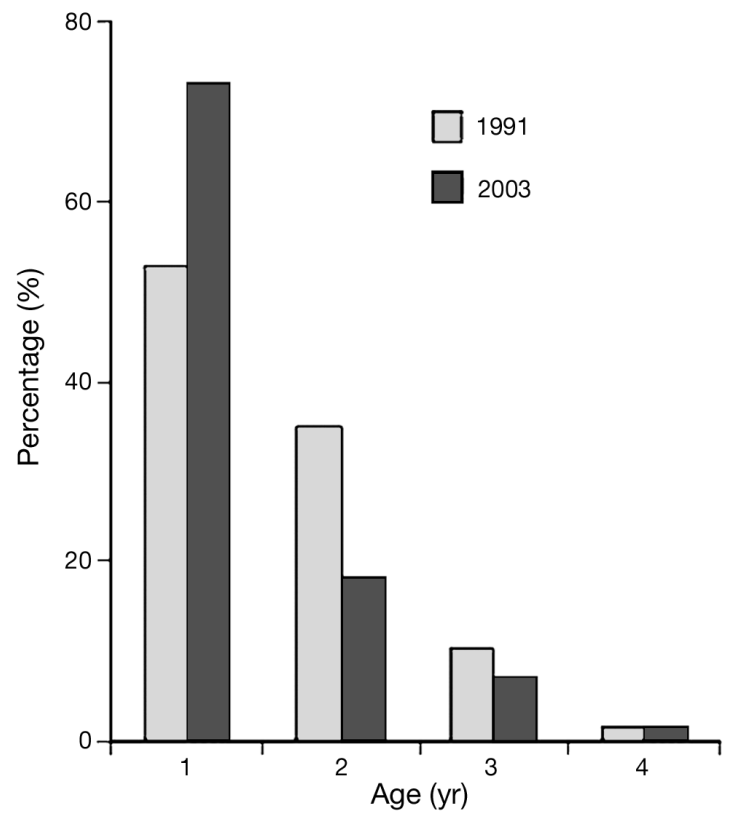

Fig. 2. Engraulis japonicus. Annual variation in age composition of anchovy spawning stock (Li et al. 2006) tainable reproduction under enormous fishing pressure (Zeng et al. 2005, Li et al. 2006).

The variation in fishery resources depends on yearclass strength, which is determined by the status of stock-recruitment relationships (Hjort 1914). The survival rate in the early life-history stages of fishes is closely related to the status of recruitment to adult

Table 1. Engraulis japonicus. Fecundity (number of eggs) within a range of fork lengths (95 to $127 \mathrm{~mm}$ ) from May to July during the periods 1985-1986 and 2002-2004 (Zeng et al. 2005). Means $\pm \mathrm{SD}$ for $\mathrm{n}$ individual fish. $F_{\mathrm{L}}$ : relative fecundity by length; $F_{\mathrm{W}}$ : relative fecundity by weight

\begin{tabular}{|c|c|c|c|}
\hline Year & $\begin{array}{l}\text { Absolute fecundity } \\
\text { (no. of eggs) }\end{array}$ & $\begin{array}{c}F_{\mathrm{L}} \\
\left(\operatorname{eggss} \mathrm{mm}^{-1}\right)\end{array}$ & $\begin{array}{c}F_{\mathrm{W}} \\
\left(\operatorname{eggs~g}^{-1}\right)\end{array}$ \\
\hline 1985-1986 & $\begin{array}{c}6187 \pm 837 \\
(\mathrm{n}=252)\end{array}$ & $\begin{array}{c}53 \pm 7 \\
(n=252)\end{array}$ & $\begin{array}{l}554 \pm 62 \\
(\mathrm{n}=252)\end{array}$ \\
\hline 2002-2004 & $\begin{array}{c}12450 \pm 537 \\
(\mathrm{n}=147)\end{array}$ & $\begin{array}{c}106 \pm 4 \\
(\mathrm{n}=147)\end{array}$ & $\begin{array}{l}987 \pm 39 \\
(\mathrm{n}=147)\end{array}$ \\
\hline$t$-test & $\begin{array}{c}t=6.2946 \\
\mathrm{p}<0.01\end{array}$ & $\begin{array}{c}t=6.7071 \\
\mathrm{p}<0.01\end{array}$ & $\begin{array}{c}t=5.9366 \\
\mathrm{p}<0.01\end{array}$ \\
\hline
\end{tabular}

Table 2. Engraulis japonicus. Fecundity (number of eggs) within a range of net body weights (5 to $14 \mathrm{~g}$ ) from May to July during the periods 1985 to 1986 and 2002 to 2004 (Zeng et al. 2005). Means $\pm \mathrm{SD}$ for $\mathrm{n}$ individual fish. $F_{\mathrm{L}}$ : relative fecundity by length; $F_{\mathrm{W}}$ : relative fecundity by weight

\begin{tabular}{|lccc|}
\hline Year & $\begin{array}{c}\text { Absolute fecundity } \\
\text { (no. of eggs) }\end{array}$ & $\begin{array}{c}F_{\mathrm{L}} \\
\left(\text { eggs } \mathrm{mm}^{-1}\right)\end{array}$ & $\begin{array}{c}F_{\mathrm{W}} \\
\left(\text { eggs g }^{-1}\right)\end{array}$ \\
\hline $1985-1986$ & $\begin{array}{c}5908 \pm 842 \\
(\mathrm{n}=252)\end{array}$ & $\begin{array}{c}51 \pm 7 \\
(\mathrm{n}=252)\end{array}$ & $\begin{array}{c}532 \pm 62 \\
(\mathrm{n}=252)\end{array}$ \\
$2002-2004$ & $\begin{array}{c}11171 \pm 542 \\
(\mathrm{n}=147)\end{array}$ & $\begin{array}{c}98 \pm 5 \\
(\mathrm{n}=147)\end{array}$ & $\begin{array}{c}999 \pm 48 \\
(\mathrm{n}=147)\end{array}$ \\
$t$-test & $\begin{array}{c}t=5.2573, \\
\mathrm{p}<0.01\end{array}$ & $\begin{array}{c}t=5.8137, \\
\mathrm{p}<0.01\end{array}$ & $\begin{array}{c}t=5.9376 \\
\mathrm{p}<0.01\end{array}$ \\
\hline
\end{tabular}


stocks (Houde 1987, 1989). It has an important role in determining abundance and has been recognized as an important factor in the fluctuation of fishery resources (Campana et al. 1989, Van der Veer et al. 1990, Hovenkamp 1992, Ellis \& Nash 1997).

As one of the key species in the marine ecosystem (Tang et al. 2005), the considerable decline of the anchovy stock has had a significant effect on the relationship between food web species in the Yellow Sea, on the structure and function of the ecosystem, on the sustainable development of marine fishery resources, and on food production (Zhao et al. 2003). Determining the survival status of the fish during early life stages will help to better understand the stock-recruitment relationships. This provides important information for management of this fisheries stock and the study of its ecosystem.

The main spawning season of the anchovy extends from March to October in the East China Sea and from April to October in the Yellow Sea. We analyzed the size and survival rate of anchovy eggs during the past 2 decades with reference to previous research results in Chinese waters and in other coastal regions of the North Pacific (Uchida 1958, Jiang \& Zheng 1984, Ruan 1984, Chen 1985, Wan \& Jiang 1998, Wan et al. 2004, Wan 2005, Wan \& Sun 2006). The longterm adaptive response of the reproductive biology of the anchovy stock under high fishing pressure is discussed. This study aims to collect basic information to better understand the early recruitment mechanism and the recruitment process of the anchovy stock, as well as to provide biological information the spawning ground surveys of anchovy in the future.

\section{MATERIALS AND METHODS}

A $5 \mathrm{yr}$ multidisciplinary investigation of the Engraulis japonicus spawning grounds in waters south of the Shandong Peninsula was conducted aboard the RV 'Beidou' of the Yellow Sea Fisheries Research Institute from May to July in 2000 to 2004. The coordinates of the research area were $33^{\circ} 30^{\prime} \mathrm{N}$ to $37^{\circ} 00^{\prime} \mathrm{N}$ and $120^{\circ} 00^{\prime}$ to $124^{\circ} 00^{\prime} \mathrm{E}$. Detailed information on the research surveys is listed in Table 3. Research stations are shown in Fig. 3. Additionally, multidisciplinary investigations, e.g. on the abundance and distribution patterns of fish eggs in the spawning grounds of Laizhou Bay (Bohai Sea) were conducted. The area for this research extended from $37^{\circ} 15^{\prime}$ to $38^{\circ} 30^{\prime} \mathrm{N}$ and $119^{\circ} 00^{\prime}$ to $121^{\circ} 00^{\prime} \mathrm{E}$; 16 stations were investigated from May to June in 2003 and 2006, and 37 stations from May to June in 2008 (Fig. 4). Also, in-
Table 3. Surveys in spawning grounds of Engraulis japonicus in waters south of Shangdong Peninsula. A = anchored station, $\mathrm{B}=$ background fixed station, $\mathrm{T}=$ thick egg area searching, $\mathrm{W}=$ water mass drift observation

\begin{tabular}{|c|c|c|c|}
\hline Date of survey & $\begin{array}{l}\text { No. of } \\
\text { stations }\end{array}$ & Method & $\begin{array}{c}\text { Geographic coordinates } \\
\text { of Stns A or W }\end{array}$ \\
\hline 13-26 Jun 2000 & 25 & B A & $\begin{array}{l}35^{\circ} 31.5^{\prime} \mathrm{N}, 122^{\circ} 31.4^{\prime} \mathrm{E} \\
34^{\circ} 59.9^{\prime} \mathrm{N}, 121^{\circ} 00.7^{\prime} \mathrm{E}\end{array}$ \\
\hline 16-22 May 2001 & 25 & B & \\
\hline 13-23 Jun 2001 & 38 & $\mathrm{~T} A$ & $\begin{array}{l}35^{\circ} 00.9^{\prime} \mathrm{N}, 121^{\circ} 00.8^{\prime} \mathrm{E} \\
34^{\circ} 52.6^{\prime} \mathrm{N}, 120^{\circ} 22.3^{\prime} \mathrm{E}\end{array}$ \\
\hline 4-8 Jul 2001 & 29 & $\mathrm{~T} A$ & $35^{\circ} 00.1^{\prime} \mathrm{N}, 120^{\circ} 59.5^{\prime} \mathrm{E}$ \\
\hline 5-11 Jun 2002 & 48 & B & \\
\hline 17-23 Jun 2002 & 30 & $\mathrm{~T} \mathrm{~W}$ & $35^{\circ} 00.0^{\prime} \mathrm{N}, 120^{\circ} 41.0^{\prime} \mathrm{E}$ \\
\hline 1-4 Jul 2002 & 30 & $\mathrm{~T} \mathrm{~W}$ & $35^{\circ} 10.6^{\prime} \mathrm{N}, 121^{\circ} 011^{\prime} \mathrm{E}$ \\
\hline 11-18 Jun 2003 & 50 & $\mathrm{~B} \mathrm{~W}$ & $35^{\circ} 01.9^{\prime} \mathrm{N}, 120^{\circ} 32.9^{\prime} \mathrm{E}$ \\
\hline 24-30 Jun 2003 & 22 & $\mathrm{~T} \mathrm{~W}$ & $\begin{array}{l}35^{\circ} 05.1^{\prime} \mathrm{N}, 120^{\circ} 35.4^{\prime} \mathrm{E} ; \\
35^{\circ} 03.3^{\prime} \mathrm{N}, 120^{\circ} 26.4^{\prime} \mathrm{E}\end{array}$ \\
\hline 10-16 Jun 2004 & 42 & B & \\
\hline $\begin{array}{l}26 \text { Jun- } \\
3 \text { Jul } 2004\end{array}$ & 20 & $\mathrm{~T} \mathrm{~W}$ & $\begin{array}{l}35^{\circ} 00.0^{\prime} \mathrm{N}, 121^{\circ} 01.0^{\prime} \mathrm{E} \\
34^{\circ} 59.0^{\prime} \mathrm{N}, 120^{\circ} 38.0^{\prime} \mathrm{E} \\
35^{\circ} 01.0^{\prime} \mathrm{N}, 120^{\circ} 35.0^{\prime} \mathrm{E}\end{array}$ \\
\hline
\end{tabular}

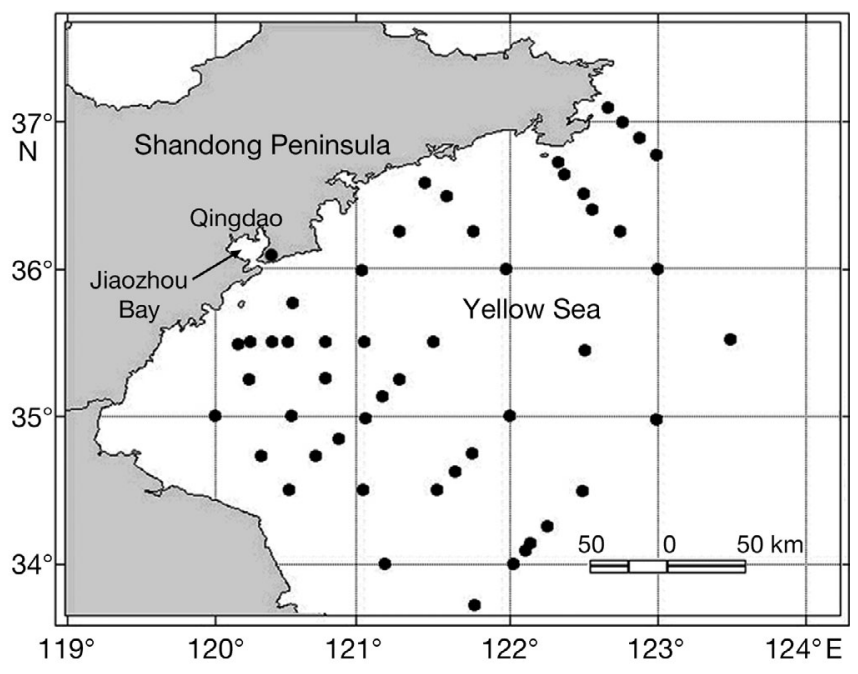

Fig. 3. Sampling stations (•) in spawning grounds of Engraulis japonicus south of the Shandong Peninsula, 2000-2004

vestigations with the same objectives were performed during fishery resource surveys in the Yellow Sea, in which the research area was from $32^{\circ} 00^{\prime}$ to $39^{\circ} 00^{\prime} \mathrm{N}$, $121^{\circ} 30^{\prime}$ to $125^{\circ} 00^{\prime} \mathrm{E}$. A total of 40 sample stations were set up in September 2006, and 70 sample stations in August 2007. Moreover, investigations on the abundance and distribution patterns of fish eggs in the coastal waters of the East China Sea were conducted from 7 to 14 May 2007. The research area was from $26^{\circ} 50^{\prime}$ to $32^{\circ} 00^{\prime} \mathrm{N}, 120^{\circ} 50^{\prime}$ to $124^{\circ} 00^{\prime} \mathrm{E}$, and 32 stations were investigated. 


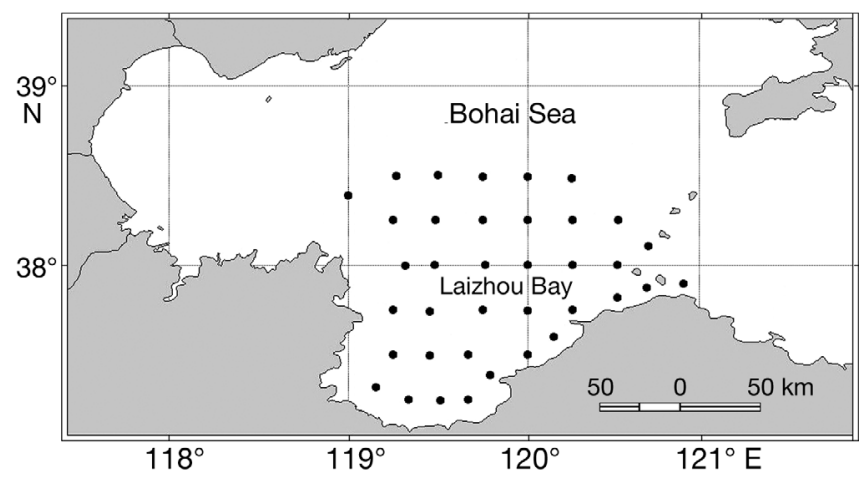

Fig. 4. Sampling stations $(\bullet)$ for Engraulis japonicus in spawning grounds in Laizhou Bay, Bohai Sea, May 2008

The eggs were collected mainly by towing a $80 \mathrm{~cm}$ diameter plankton net with a mesh size of $0.50 \mathrm{~mm}$ along the sea surface. The trawling speed was 3.0 nautical mile $\mathrm{h}^{-1}$ for $10 \mathrm{~min}$ at each station. The samples were fixed in $5 \%$ formalin seawater.

Individual counts, developmental stages, and the egg mortality of the anchovy eggs were determined using a Nikon SMZ1500 photomicroscope equipped with a micrometer ocular lens. Furthermore, the size of anchovy eggs collected both in the spawning grounds off the south Shandong Peninsula from 16 to 29 June 2003 and in the coastal waters of the East China Sea from 7 to 14 May 2007 was measured. However, malformed eggs at the gastrula and embryonic developmental stages were not calculated in measurement of non-viable egg sizes.

The structural basis for discrimination of nonviable eggs includes the lack of a transparent egg membrane; turbidity of the entire egg, with no discernable structures (Fig. 5a); loose, cracked, or broken yolk sacs (Fig. 5b); incomplete epiboly on the underside of the yolk sac, parts of the yolk sac, or tissue free in the egg chamber in the blastula (Fig. 5c-f); and malformations in the blastodisc, blastomeres (Fig. 5g,h), blastula (Fig. 5c), or the embryo (Fig. 5e,f). (Fig. 6a-e) illustrates different developing stages of viable eggs to enable comparison with dead ones. Photographs of eggs were taken by a Nikon SMZ1500.

The methods of sampling anchovy eggs used in our previous studies are described in Table 3.

Egg size variation at the gastrula, tail-bud, and embryonic stages in the spawning grounds off south Shandong Peninsula and in the coastal waters of the East China Sea was examined (Table 4) and initially tested separately by Kruskal-Wallis 1-way ANOVA. A Mann-Whitney $U$-test was used to examine the size variations between viable and non-viable eggs within the spawning grounds off south Shandong Peninsula and in the coastal waters of the East China Sea separately. Variations in the size of viable eggs between spawning grounds off south Shandong Peninsula and in the coastal waters of the East China
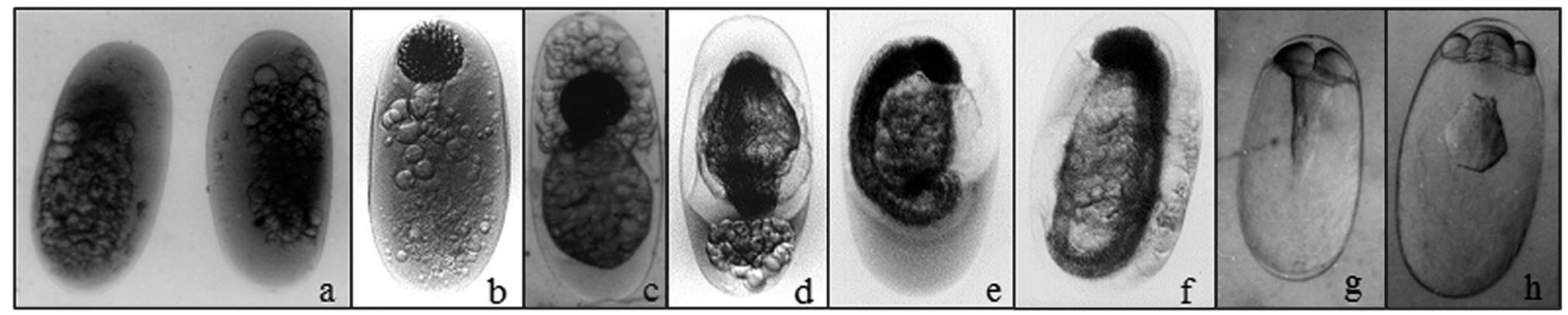

Fig. 5. Engraulis japonicus. Malformations during embryonic development: (a) turbidity of the entire egg with no discernable structures; (b) loose and broken yolk sac; $(c, d)$ incomplete epiboly on the underside of the yolk sac, parts of the yolk sac, or tissue free in the egg chamber in the blastula, malformations in embryonic development; $(\mathrm{e}, \mathrm{f})$ parts of the yolk sac, or tissue free in the egg chamber, malformations in the blastodisc; $(g, h)$ malformations in the blastomeres
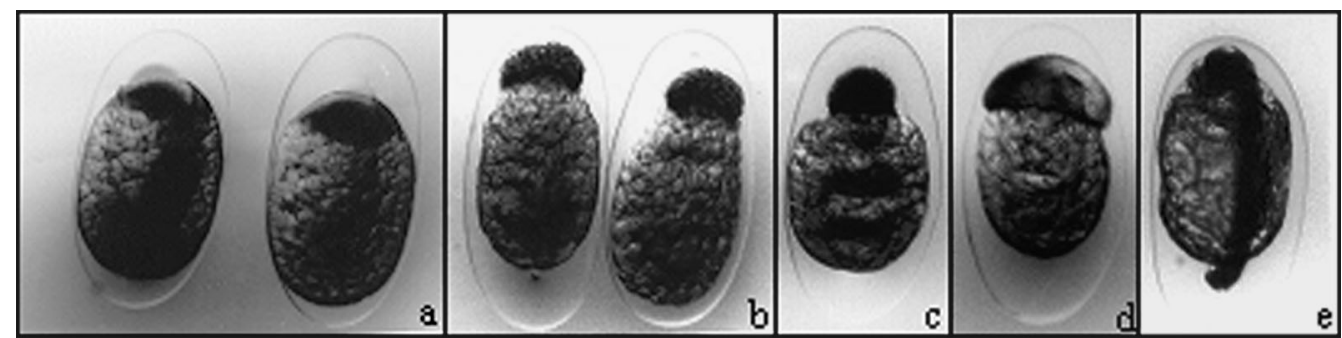

Fig. 6. Engraulis japonicus. Normal eggs during embryonic development: (a) unsegmented fertilized, (b) late cleavage stage, (c) early blastula stage, (d) late blastula stage, and (e) embryo three-quarters around yolk sac 
Table 4. Engraulis japonicus. Anchovy egg size given as a range and mean \pm SD (in parentheses). $\mathrm{n}=\mathrm{number}$ of samples

\begin{tabular}{|c|c|c|c|c|c|c|}
\hline Area & Developmental stage & Long axis (mm) & Short axis (mm) & Volume $\left(\mathrm{mm}^{3}\right)$ & $\mathrm{n}$ & Source \\
\hline \multirow{5}{*}{$\begin{array}{l}\text { Spawning grounds } \\
\text { off south Shandong } \\
\text { Peninsula } \\
\text { (16-29 Jun 2003) }\end{array}$} & $\begin{array}{l}\mathrm{s} \\
\mathrm{g}\end{array}$ & $\begin{array}{c}1.20-1.26 \\
(1.24 \pm 0.01)\end{array}$ & $\begin{array}{c}0.60-0.66 \\
(0.63 \pm 0.01)\end{array}$ & $\begin{array}{c}0.234-0.278 \\
(0.256 \pm 0.011)\end{array}$ & 100 & \multirow[t]{10}{*}{ Present study } \\
\hline & Gastrula stage & $\begin{array}{c}1.20-1.34 \\
(1.28 \pm 0.04)\end{array}$ & $\begin{array}{c}0.60-0.68 \\
(0.64 \pm 0.02)\end{array}$ & $\begin{array}{c}0.226-0.310 \\
(0.276 \pm 0.021)\end{array}$ & 88 & \\
\hline & Tail-bud stage & $\begin{array}{c}1.22-1.40 \\
(1.29 \pm 0.04)\end{array}$ & $\begin{array}{c}0.60-0.68 \\
(0.64 \pm 0.02)\end{array}$ & $\begin{array}{c}0.230-0.339 \\
(0.281 \pm 0.023)\end{array}$ & 68 & \\
\hline & Embryonic stage & $\begin{array}{c}1.22-1.36 \\
(1.27 \pm 0.03)\end{array}$ & $\begin{array}{c}0.60-0.68 \\
(0.64 \pm 0.02)\end{array}$ & $\begin{array}{c}0.230-0.330 \\
(0.276 \pm 0.024)\end{array}$ & 76 & \\
\hline & Viable eggs & $\begin{array}{c}1.20-1.40 \\
(1.28 \pm 0.04)\end{array}$ & $\begin{array}{c}0.60-0.68 \\
(0.64 \pm 0.02)\end{array}$ & $\begin{array}{c}0.226-0.339 \\
(0.278 \pm 0.023)\end{array}$ & 232 & \\
\hline \multirow{5}{*}{$\begin{array}{l}\text { Coastal waters } \\
\text { of the East } \\
\text { China Sea } \\
\text { (7-14 May 2007) }\end{array}$} & Non-viable eggs & $\begin{array}{c}1.10-1.39 \\
(1.25 \pm 0.06)\end{array}$ & $\begin{array}{c}0.55-0.67 \\
(0.62 \pm 0.02)\end{array}$ & $\begin{array}{c}0.192-0.309 \\
(0.254 \pm 0.025)\end{array}$ & 133 & \\
\hline & Gastrula stage & $\begin{array}{c}1.12-1.40 \\
(1.28 \pm 0.07)\end{array}$ & $\begin{array}{c}0.55-0.68 \\
(0.63 \pm 0.03)\end{array}$ & $\begin{array}{c}0.204-0.338 \\
(0.264 \pm 0.031)\end{array}$ & 145 & \\
\hline & Tail-bud stage & $\begin{array}{c}1.12-1.39 \\
(1.30 \pm 0.04)\end{array}$ & $\begin{array}{c}0.55-0.68 \\
(0.64 \pm 0.02)\end{array}$ & $\begin{array}{c}0.184-0.313 \\
(0.268 \pm 0.025)\end{array}$ & 72 & \\
\hline & Embryonic stage & $\begin{array}{c}1.19-1.38 \\
(1.26 \pm 0.04)\end{array}$ & $\begin{array}{c}0.56-0.68 \\
(0.63 \pm 0.02)\end{array}$ & $\begin{array}{c}0.203-0.314 \\
(0.260 \pm 0.022)\end{array}$ & 86 & \\
\hline & Viable eggs & $\begin{array}{c}1.12-1.40 \\
(1.28 \pm 0.06)\end{array}$ & $\begin{array}{c}0.55-0.68 \\
(0.63 \pm 0.03)\end{array}$ & $\begin{array}{c}0.184-0.338 \\
(0.264 \pm 0.028)\end{array}$ & 303 & \\
\hline \multicolumn{2}{|c|}{$\begin{array}{l}\text { Jiaozhou Bay in Yellow Sea } \\
\text { (14 May-3 Jun 1963) }\end{array}$} & $\begin{array}{c}1.21-1.71 \\
1.34^{\mathrm{a}}\end{array}$ & $\begin{array}{l}0.57-0.85 \\
0.67^{\mathrm{a}}\end{array}$ & $0.315^{\mathrm{a}}$ & \multicolumn{2}{|r|}{ Ruan (1984) } \\
\hline \multicolumn{2}{|c|}{ East China Sea (1958-1964) } & $1.08-1.57$ & $0.55-0.70$ & & \multicolumn{2}{|r|}{ Chen (1985) } \\
\hline \multicolumn{2}{|c|}{$\begin{array}{l}\text { Fishing ground of the south Fujian } \\
\text { and Taiwan Bank (Apr 1974-Mar 1977) }\end{array}$} & $\begin{array}{c}1.16-1.40 \\
1.29^{\mathrm{b}}\end{array}$ & $\begin{array}{l}0.60-0.71 \\
0.63^{\mathrm{b}}\end{array}$ & $0.268^{\mathrm{b}}$ & \multicolumn{2}{|c|}{ Jiang \& Zheng (1984) } \\
\hline \multicolumn{2}{|c|}{ Coastal ocean of Japan (1958) } & $1.4-1.6$ & $0.6-0.7$ & & \multicolumn{2}{|r|}{ Uchida (1958) } \\
\hline
\end{tabular}

Sea were determined by Mann-Whitney U-test. A one-sample $t$-test was run to determine the variations in anchovy egg size between the current study and previous research results in Chinese waters from the 1950s to 1970s. The volume of anchovy eggs used in comparisons was calculated as:

$$
\text { Egg volume }=\frac{4}{3} \pi \times \frac{(\text { long axes })}{2} \times\left[\frac{(\text { short axes })}{2}\right]^{2}
$$

Natural mortality rates of anchovy eggs, i.e. the percentage of naturally occurring dead eggs, was calculated based on the abundance of dead anchovy eggs and the abundance of all eggs examined during 1 cruise:

Non-viable eggs $(\%)=\frac{\text { No. of non-viable eggs }}{\text { No. of total eggs }} \times 100 \%$

Natural mortality rates of anchovy eggs in the Bohai Sea, Yellow Sea, and East China Sea surveys (Table 5) after 1990 were compared with the survey results from the 1980s (Table 5) in the Yellow Sea by using the chi-squared test.

\section{RESULTS}

\section{Changes in size of the anchovy egg}

Engraulis japonicus eggs are ellipsoid, isolated, and pelagic (Uchida 1958, Jiang \& Zheng 1984, Ruan 1984, Chen 1985). The analysis of the measurements showed that there was no variation in the size of anchovy eggs at the gastrula, tail-bud, or embryonic stages in spawning grounds off the south Shandong Peninsula $\left(H_{(2, \mathrm{n}=232)}=0.923, \mathrm{p}=0.6302>\right.$ 0.05; Kruskal-Wallis 1-way ANOVA) or in the coastal waters of the East China Sea $\left(H_{(2, \mathrm{n}=303)}=\right.$ $2.64, \mathrm{p}=0.267>0.05$; Kruskal-Wallis 1-way ANOVA) (Table 4). The viable eggs off the southern Shandong Peninsula had long axes ranging from 1.20 to $1.40 \mathrm{~mm}(1.28 \pm 0.04 \mathrm{~mm})$ and short axes from 0.60 to $0.68 \mathrm{~mm}(0.64 \pm 0.02 \mathrm{~mm})$. The non-viable eggs, with long axes ranging from 1.20 to $1.26 \mathrm{~mm} \mathrm{(1.24 \pm}$ $0.01 \mathrm{~mm}$ ) and short axes ranging from 0.60 to $0.66 \mathrm{~mm}(0.63 \pm 0.01)$, were significantly smaller than viable eggs $(U=1298.5, \mathrm{p}<0.01$; Mann-Whit- 
Table 5. Engraulis japonicus. Natural mortality rates of anchovy eggs. $\mathrm{n}=$ number of eggs

\begin{tabular}{|c|c|c|c|c|}
\hline Survey area & Survey time & $\mathrm{n}$ & Non viable eggs $(\%)$ & Source \\
\hline Spawning grounds off south & 13-18 Jun 2000 & 28907 & 83.41 & Present study \\
\hline \multirow[t]{5}{*}{ Shandong Peninsula } & 16 May-6 Jul 2001 & 86872 & 84.87 & \\
\hline & 5-20 Jun 2002 & 51231 & 81.34 & \\
\hline & 11-17 Jun 2003 & 175115 & 80.42 & \\
\hline & 10-19 Jun 2004 & 124510 & 75.22 & \\
\hline & Total & 466635 & 80.15 & \\
\hline \multirow[t]{3}{*}{ Yellow Sea } & Sep 2006 & 344 & 77.33 & \\
\hline & Aug 2007 & 3473 & 77.66 & \\
\hline & Total & 3817 & 77.63 & \\
\hline \multirow[t]{6}{*}{ Laizhou Bay of Bohai Sea } & May 2003 & 116194 & 82.52 & \\
\hline & May 2004 & 8391 & 87.70 & \\
\hline & Jun 2005 & 4311 & 70.38 & \\
\hline & May 2006 & 11575 & 87.02 & \\
\hline & May-Jun 2008 & 10035 & 84.68 & \\
\hline & Total & 150506 & 82.95 & \\
\hline East China and Yellow Seas & 26 Mar-24 Apr 2001 & 14379 & 88.09 & Wan \& Sun (2006) \\
\hline Yellow Sea & 15 May-18 Dec 1998 & 59838 & 83.57 & Wan (2005) \\
\hline Bohai Sea & 25 May-16 Oct 1998 & 118933 & 91.33 & Wan et al. (2004) \\
\hline Yellow Sea & 11 Mar-14 Jun 1985 & 800999 & 64.10 & Wan \& Jiang (1998) \\
\hline
\end{tabular}

ney $U$-test). The viable eggs in the coastal waters of the East China Sea had long axes ranging from 1.12 to $1.40 \mathrm{~mm}(1.28 \pm 0.06 \mathrm{~mm})$ and short axes ranging from 0.55 to $0.68 \mathrm{~mm}(0.63 \pm 0.03 \mathrm{~mm})$. The nonviable eggs, with long axes ranging from 1.10 to $1.39 \mathrm{~mm}(1.25 \pm 0.06 \mathrm{~mm})$ and short axes ranging from 0.55 to $0.67 \mathrm{~mm}(0.62 \pm 0.02 \mathrm{~mm})$, were also significantly smaller than viable eggs $(U=13423$, $\mathrm{p}=0.002<0.01$; Mann-Whitney $U$-test).

The anchovies distributed in the Northwest Pacific Ocean belong to the same population (Liu et al. 2006). The geographical distribution area includes the western and northern East China Sea, the Yellow Sea, the Sea of Japan, the western coast of Kyushu in Japan, the Seto Inland Sea, and the Pacific coast of the Japanese archipelago (Whitehead et al. 1988). Thus, the anchovy eggs from different sea areas were comparable in size. The anchovy eggs collected at the spawning grounds off the south Shandong Peninsula from 16 to 29 June 2003, were significantly smaller than those collected in Jiaozhou Bay of the Yellow Sea from 14 May to 3 June $1963(t=-26.479$, df $=231$, tested value $=$ $0.629, \mathrm{p}<0.01 ; 1$-sample $t$ test) (Table 4$)$. The anchovy eggs collected in the coastal waters of the East China Sea in May 2007 were slightly smaller than those collected in the same areas from 1958 to 1964 (Table 4), but they were significantly smaller than those collected at the fishing ground off the southern Fujian and Taiwan Bank from April 1973 to March 1977 ( $t=-2.409$, df $=302$, tested value $=$ $0.536, \mathrm{p}=0.017<0.05$; 1 -sample $t$-test). Also, the anchovy eggs currently collected were significantly smaller than those distributed off the coasts of Japan in 1958 (Table 4). The comparison above indicates that the egg size both in the spawning grounds off the south Shandong Peninsula and in the coastal waters of the East China Sea decreased significantly under the enormous fishing pressure.

The spawning grounds off the south Shandong Peninsula are located at a higher latitude than the coastal waters of the East China Sea. As a rule, egg sizes of a certain teleost species increase with increasing latitude (Xia \& Liu 1981). Though the anchovy stock has undergone serious decline in just $10 \mathrm{yr}$, the anchovy eggs currently collected at spawning grounds off south Shandong Peninsula were still significantly larger than those collected in the coastal waters of the East China Sea $(U=11875$, p $<0.01$; Mann-Whitney $U$-test). This coincides with the rule of geographical variation.

\section{Natural mortality rates of anchovy eggs}

Based on a 5 yr consecutive survey performed at the spawning grounds off south Shandong Peninsula during May to June from 2000 to 2004, the natural mortality rates of anchovy eggs were always $>80 \%$, except for that from 10 to 19 June 2004 when it was 
only $75.22 \%$. The 5 yr total mean natural mortality rate of anchovy eggs was $80.15 \%$ (Table 5). The natural mortality rate of anchovy eggs is $77.63 \%$ according to Yellow Sea fishery resource surveys conducted in September 2006 and August 2007 (Table 5). The natural mortality rate of anchovy eggs in Laizhou Bay of Bohai Sea also reached $>80 \%$ from May 2003 to June 2008, except in June 2005, when the natural mortality rate was only $70 \%$. The $5 \mathrm{yr}$ total mean natural mortality rate of anchovy eggs distributed in Laizhou Bay of the Bohai Sea was 82.95\% (Table 5). In this study, non-viable eggs included those with malformations at embryonic developmental stages (Bunn et al. 2000).

Based on the data outlined in Table 5, the natural mortality rates of anchovy eggs in the Bohai Sea, the Yellow Sea, and the East China Sea have all reached up to $80 \%$ since the late 1990s. Compared with the 1980s survey results in the Yellow Sea, the natural mortality rates of anchovy eggs showed a significantly rising trend under the enormous fishing pressure there $\left(\chi^{2}=38.88, \mathrm{df}=5, \mathrm{p}<0.01\right.$; chisquared test).

Based on microscopial inspection of total egg numbers, 5 to $10 \%$ of the $>80 \%$ of non-viable anchovy eggs were fertilized and developed to either the gastrula stage or the late embryonic stage. However, among the rest it could not be discriminated whether they were fertilized or not.

\section{DISCUSSION}

The high natural mortality rate of fish eggs reduces the effective fecundity of the brood stock (Anderson 1988). In particular, given the severe decline of the anchovy Engraulis japonicus stock in recent years, the significant increase in mortality rates of anchovy eggs is extremely unfavorable for the recovery of anchovy resources, which may even affect the balance of the marine ecosystem (Zhao et al. 2003). The numerous factors that cause natural mortality of fish eggs can be broadly divided into 2 categories, exogenous and endogenous (Heath 1992). Exogenous causes include predation (Hunter \& Kimbrell 1980, Toesen 1985), diseases and parasites (Ojaveer 1981, Menses \& Ré 1989), effects of harmful and toxic algae (Aneer 1987), pollutants (Longwell \& Hughes 1981), and physical damage (Wood 1981). Endogenous sources of mortality stem from inherited genetic, physiologic, or other non-external factors that induce dysplasia (Heath 1992), such as poor quality of eggs and sperm (Kjørsvik et al. 1990) and fertilization restrictions (the relative density of sperm and eggs or unfavorable aquatic environment) among other factors (Bobe \& Labbé 2010). The quality of eggs, immature or overmature, may result in failed fertilization or abnormal development after fertilization (McEvoy $\&$ McEvoy 1992). However, until now, much of the mechanism through which endogenous factors cause mortality of fish eggs remains unclear (Bunn et al. 2000, Bobe \& Labbé 2010).

Anchovies are multiple spawners typically displaying group-synchronous ovary development and batch spawning (Funamoto \& Aoki 2002). Egg quality among the different age groups of the spawning stock varies greatly (Solemdal et al. 1995). Variations may also exist among different batches (McEvoy \& McEvoy 1992). A significant proportion of anchovy eggs spawned in the field may have been unsuitably mature, which led to the high mortality rate of the eggs. Moreover, egg mortality of first-time spawners is significantly higher than that of repeat spawners in the same spawning stock (Solemdal 1997). Additionally, gonadal development and the quality of eggs and sperm are significantly affected by the lower age and decreased mean length of anchovy spawning stock (Li et al. 2006), as well as by significantly increased individual fecundity (Zeng et al. 2005). All of these factors could affect fertilization rates, causing a marked increase in the mortality rates of anchovy eggs (Bobe \& Labbé 2010).

In anchovy, ovulation, ejaculation, and fertilization of the brood stock all occur within a short period. The abundance and density of the spawning stock sharply dropped due to the decline in anchovy resources (Li et al. 2006). These changes might affect the relative density of eggs and sperm in the aquatic environment, thereby causing the low fertilization rates and significantly increased mortality of eggs. Thus, it is necessary to conduct further studies on spawning behavior, including the duration of egg viability after ovulation and the initiation of the fertilization process.

Pseudo-gamy and pseudo-cleavage also occur in teleost eggs (Lou \& Zheng 1981). Accurately determining egg status, i.e. whether they are already fertilized or not, through a morphologic method is difficult. Thus, non-viable eggs that had developed until the cell division stage were not included in the aforementioned $80 \%$ natural mortality rate. Consequently, mortality rates might be slightly underestimated. To better understand the mechanism of early recruitment in the anchovy stock, the causes of egg mortality should be interpreted; the fertilization status of non-viable eggs, including those that develop 
to the cell division stage, should be determined; and the endogenous and exogenous factors, as well as the pathogenesis of mortality should be clarified. The standard cytological features of fertilized and pseudo-gamy eggs should be defined to provide a more reliable basis for testing samples collected in the field. Therefore, determination of fertilization status of non-viable eggs is one of the most important scientific issues in studying the process and mechanism behind anchovy recruitment. Furthermore, monitoring of the anchovy fishery, as well as regulating the fishing effort and fishing capacity to ensure sustainable utilization of the anchovy stock, is of great significance.

The size of anchovy eggs declined in the spawning grounds off south Shandong Peninsula and in the coastal waters of the East China Sea. Non-viable eggs were significantly smaller than the viable ones.

A characteristic trend towards lower age and decreased mean length has been reported for the anchovy spawning stock (Li et al. 2006). Moreover, individual fecundity has increased at comparable fork lengths and weight ranges (Zeng et al. 2005). All of the above have contributed to decreases in anchovy egg size. The perivitelline spaces of the eggs swelled insufficiently due to the absorption of water, causing non-viable eggs to be significantly smaller than viable eggs, both in the spawning grounds off south Shandong Peninsula ( $U=1298.5, \mathrm{p}$ $<0.01$; Mann-Whitney $U$-test) and in the coastal waters of the East China Sea $(U=13423, \mathrm{p}=0.002<$ 0.01; Mann-Whitney $U$-test).

The decreased size and significantly increased natural mortality rates of anchovy eggs are longterm adaptive responses, via the reproductive biology of the anchovy population, to an enormous fishing pressure.

Acknowledgements. The study was financially supported by the National Natural Science Foundation of China (Grant no. 31272667), the Major State Global Change Research Program of China (Grant no. 2010CB951204), the National Key Basic Research Program from the Ministry of Science and Technology of China (Grant no. 2011CB409805 and 2006CB400608), and the Scientific Observing and Experimental Station of Fishery Resources and Environment of Yellow Sea and Bohai Sea, Ministry of Agriculture, China. We greatly appreciated the help of Dr. Kenneth Sherman during the evaluation process and by improving the English of the manuscript. We thank a number of anonymous reviewers for their valuable comments. We also thank the captain, the chief engineer, and the crew aboard the RV 'Beidou' and colleagues for their support in collecting samples.

\section{LITERATURE CITED}

Anderson JT (1988) A review of size dependent survival during pre-recruit stages of fishes in relation to recruitment. J Northwest Atl Fish Sci 8:55-66

Aneer G (1987) High natural mortality of Baltic herring (Clupea harengus) eggs caused by algal exudates? Mar Biol 94:163-169

Bobe J, Labbé C (2010) Egg and sperm quality in fish. Gen Comp Endocrinol 165:535-548

Bunn NA, Fox CJ, Webb TA (2000) Literature review of studies on fish egg mortality: implications for the estimation of spawning stock biomass by the annual egg production method. In: Science Series Technical Report III. CEFAS, Lowestoft, p 1-37

Campana SE, Frank KT, Hurley PCF, Koeller PA, Page FH, Smith PC (1989) Survival and abundance of young Atlantic cod (Gadus morhus) and haddock (Melanogrammus aeglefinus) as indicators of year-class strength. Can J Fish Aquat Sci 46:171-182

Chen LF (1985) Engraulis japonica Temminck \& Schlegel. In: Zhao CY, Zhang RZ (eds) Fish eggs and larvae in the offshore waters of China. Shanghai Science and Technology Press, Shanghai, p 27-28 (in Chinese with English abstract)

Ellis T, Nash RDM (1997) Predation by sprat and herring on pelagic fish eggs in plaice spawning area in the Irish Sea. J Fish Biol 50:1195-1202

Funamoto T, Aoki I (2002) Reproductive ecology of Japanese anchovy off the Pacific coast of eastern Honshu, Japan. J Fish Biol 60:154-169

$>$ Heath MR (1992) Field investigations of the early life stages of marine fish. Adv Mar Biol 28:1-174

Hjort J (1914) Fluctuations in the great fisheries of northern Europe viewed in the light of biological research. Rapp p-v Reun Cons Perm Int Explor Mer 20:1-228

Houde ED (1987) Fish early life dynamics and recruitment variability. Am Fish Soc Symp 2:17-29

Houde ED (1989) Subtleties and episodes in the early life of fishes. J Fish Biol 35:29-38

Hovenkamp F (1992) Growth-dependent mortality of larval plaice Pleuronectes platessa in the North Sea. Mar Ecol Prog Ser 82:95-101

Hunter JR, Kimbrell CA (1980) Egg cannibalism in the northern anchovy, Ehgraulis mordax. Fish Bull 78: 811-816

Jiang SF, Zheng XY (1984) The morphological characters of eggs and larvae of Engraulis japonicus Temminck et Schlegel and its spawning area in the fishing ground of the south Fujian and Taiwan Bank. Taiwan Strait 3: 224-231 (in Chinese with English abstract)

Kjørsvik E, Jensen MA, Holmefjord L (1990) Egg quality in fishes. Adv Mar Biol 26:71-113

Li XS, Zhao XY, Li F, Li FG, Dai FQ, Zhu JC (2006) Structure and its variation of anchovy (Engraulis japonicus) spawning stock in the southern waters to Shandong Peninsula. Mar Fish Res 27:46-53 (in Chinese with English abstract)

> Liu JX, Gao TX, Zhuang ZM, Jin XS, Yokogawa K, Zhang YP (2006) Late pleistocene divergence and subsequent population expansion of two closely related fish species, Japanese anchovy (Engraulis japonicus) and Australian anchovy (Engraulis australis). Mol Phylogenet Evol 40: 712-723

Longwell AC, Hughes JB (1981) Cytological, cytogenetic, and embryological state of Atlantic mackerel eggs from 
surface waters of the New York Bight in relation to pollution. Rapp p-v Reun Cons Perm Int Explor Mer 178: $67-78$

Lou YD, Zheng DC (1981) Histology and embryology. Agriculture Press, Beijing, p 303-343 (in Chinese)

McEvoy LA, McEvoy J (1992) Multiple spawning in several commercial fish species and its consequences for fisheries management, cultivation and experimentation. J Fish Biol 41(Suppl b):125-136

Menses I, Ré P (1989) Infection of sardine eggs by a parasitic dinoflagellate (Ichthyodinium chablardi) off Portugal. Rapp p-v Reun Cons Perm Int Explor Mer 191:442

Ojaveer E (1981) On embryonal mortality of spring spawning herring on spawning grounds in the northeastern Gulf of Riga. Rapp p-v Reun Cons Perm Int Explor Mer 178:401

Ruan HC (1984) Studies on the eggs and larvae of Engraulis japonicus. Stud Mar Sin 22:29-56 (in Chinese with English abstract)

Solemdal P (1997) Maternal effects - a link between the past and the future. J Sea Res 37:213-227

Solemdal P, Kjesbu OS, Fonn M (1995) Egg mortality in recruit- and repeat-spawning cod-an experimental study. ICES CM 1995/G:35

Tang QS, Su JL, Sun S, Zhang J, Huang DJ, Jin XS, Tong L (2005) A study of marine ecosystem dynamics in the coastal ocean of China. Adv Earth Sci 20:1288-1299 (in Chinese with English abstract)

Toesen R (1985) Predation on the eggs of Norwegian spring spawned herring at a spawning ground outside the west coast of Norway in 1981. ICES CM 1985, H:55, 1-16

Uchida K (1958) Engraulis japonicus (Houttuyn). In: Uchida K, Imai S, Mito S, Fujita S, Ueno M, Shojima Y, Senta T, Tahuku M, Dotsu Y (eds) Studies on the eggs, larvae and juvenile of Japanese fishes, Series 1. Second Laboratory of Fisheries Biology, Fisheries Department, Faculty of Agriculture, Kyushu University, Fukuoka, p 17-18 (in Japanese with English abstract)

Van der Veer HW, Pihl L, Bergman MJN (1990) Recruitment mechanisms in North Sea plaice Pleuronectes platessa. Mar Ecol Prog Ser 64:1-12

Wan RJ (2005) Fish eggs and larvae. In: Jin XS, Zhao XY, Meng XT, Cui Y (eds) The living resources and its habitat in the Yellow Sea and Bohai Sea. Science Press, Beijing, p 108-124 (in Chinese)

Wan RJ, Jiang YW (1998) Studies on the ecology of eggs and

Editorial responsibility: Kenneth Sherman,

Narragansett, Rhode Island, USA larvae of osteichthyes in the Yellow Sea. Mar Fish Res 19: 60-73 (in Chinese with English abstract)

Wan RJ, Sun S (2006) The category composition and abundance of ichthyoplankton in the ecosystem of the Yellow Sea and the East China Sea. Acta Zool Sin 52:28-44 (in Chinese with English abstract)

Wan RJ, Zhang PC, Li PJ, Qiu SY (2004) Fish eggs, larvae and their ecological characteristics. In: Cheng JS, Qiu SY, Li PJ, Cui Y (eds) Environments and communities in coastal waters of the Yellow Sea and Bohai Sea. Ocean University of China Press, Qingdao, p 343-367 (in Chinese)

Wei S, Jiang WM (1992) Study on food web of fishes in the Yellow Sea. Oceanol Limnol Sin 23:182-192 (in Chinese with English abstract)

Whitehead PJP, Nelson GJ, Wongratana T (1988) FAO species catalogue. Clupeoid fishes of the world (Suborder Clupeoidei). An annotate and illustrated catalogue of the herring, sardine, pilchards, sprats, shads, anchovies and wolf-herrings. Part 2. Engraulidae, Vol. 7. FAO Fisheries Synopsis, Rome

Wood RJ (1981) The Thames Estuary herring stock. Fish Res Tech Rep, MAFF Direct Fish Res, Lowestoft 64:1-21

Xia SF, Liu XS (1981) Handbook for marine fishery resource survey, 2nd edn. Shanghai Science and Technology Press, Shanghai, p 103 (in Chinese)

Zeng L, Li XS, Zhao XY, Li F, Jin XS (2005) Fecundity and its variations of anchovy Engraulis japonicus in the central and southern Yellow Sea. J Fish Sci China 12:569-574 (in Chinese with English abstract)

Zhao XY (2006) Population dynamic characteristics and sustainable utilization of the anchovy stock in the Yellow Sea. PhD thesis, Ocean University of China, Qingdao, p 1-135 (in Chinese with English abstract)

Zhao X, Hamre J, Li F, Jin X, Tang Q (2003) Recruitment, sustainable yield and possible ecological consequences of the sharp decline of the anchovy (Engraulis japonicus) stock in the Yellow Sea in the 1990s. Fish Oceanogr 12: 495-501

Zhu DS, Iversen SA (1990) Anchovy and other fish resources in the Yellow Sea and East China Sea. Mar Fish Res 11: 1-143 (in Chinese with English abstract)

Zhu JC, Zhao XY, Li FG (2007) Growth characters of the anchovy stock in the Yellow Sea with its annual and seasonal variations. Mar Fish Res 28:64-72 (in Chinese with English)

Submitted: October 20, 2011; Accepted: April 27, 2012 Proofs received from author(s): September 18, 2012 